\title{
The Grammatical Awareness of Student Teachers: The Case of an English Education Study Program in Indonesia
}

\author{
Lenny Marzulina', Amirul Mukminin 2,", Dian Erlina ${ }^{1}$, Annisa Astrid ${ }^{1}$, Ni’matul Ajriyah $^{1}$, \\ Muhamad Holandiyah ${ }^{1}$, Akhmad Habibi ${ }^{2}$ \\ ${ }^{1}$ Faculty of Tarbiyah and Teaching Sciences, Universitas Islam Negeri Raden Fatah Palembang, Indonesia \\ ${ }^{2}$ Doctoral Program in Education, Graduate School, Universitas Jambi, Indonesia
}

Copyright $(2019$ by authors, all rights reserved. Authors agree that this article remains permanently open access under the terms of the Creative Commons Attribution License 4.0 International License

\begin{abstract}
The aims of this study were to find out student teachers' grammatical awareness and their perception towards grammatical awareness. This study employed a mixed method research. The participants were 129 English Education Study Program's student teachers at one state Islamic University in Indonesia. Purposeful sampling technique was applied to choose the participants. To collect the quantitative data, grammatical test was used and interview was used to obtain qualitative data. 129 student teachers took the test and 12 of them were willing to participate in the interview. The results indicated that student teachers had four types of grammatical awareness, namely (1) metalanguage recognition, (2) metalanguage production, (3) identification and grammatical error correction, and (4) grammatical rules explanation. The student teachers lacked of grammatical awareness. It could be seen from their ability to explain grammatical mistakes. Rules in grammar and explanation tasks were the most difficult for them whereas the easiest one was a metalanguage recognition task. The major factor of their weakness was the complexity of the rules of tenses.
\end{abstract}

Keywords Grammatical Awareness, Grammatical Mistakes, Rules of Tenses, Student Teachers

\section{Introduction}

Nowadays, English as a global language has some advantages to people around the world. English is used as a language to communicate across national borders. Using English to communicate may also help people to know, understand and respect each other particularly those who have different backgrounds such as languages, cultures and ethnics (Mukminin, Ali, \& Ashari, 2015). Besides, it is as a bridge to solve differences such as conflicts across the country globally, these conflicts are mostly avoidable with mediation and negotiation through English as a medium of communication (Pandarangga, 2015). English as a global language has united and connected all the people worldwide in terms of communication and it solve differences (Habibi, Mukminin, Najwan, Sofwan, Haswindy, Marzulina, Sirozi, \& Harto, 2018; Makmur, Mukminin, Ismiyati, \& Verawati 2016).

In Indonesia, English is considered as a foreign language. English is regarded as one of the most popular foreign languages (Abrar et al., 2018; Husarida, \& Dollete, 2019). In addition, Marzulina et al. (2018) argue that English is one of the compulsory subjects in Indonesia's educational system. Besides, the law 2003 on the curriculum of higher education includes a foreign language, especially English as a subject and it is an elective to be master. In brief, English as a foreign language in Indonesia and it has become a compulsory subject for the students (Mukminin, Masbirorotni, Noprival, Sutarno, Arif, \& Maimunah, 2015; Mukminin, Haryanto, Sutarno, Sari, Marzulina, Hadiyanto, \& Habibi, 2018).

Furthermore, there are four language skills in English that should be mastered by students; listening, speaking, reading, and writing. Harmer (2007) states that learning integrated English skills may make students easy to learn the language because the four skills are related to each other in learning English. In addition, the integration of the four skills of the English language in fact influences the students' performance (Batias, Sepulveda, Munoz, \& Lorena, 2011). Therefore, the students should learn about all of the skills to master English well.

In studying English, English grammar occupies a central position because it is one of the elements of the language which should be mastered. Mastering grammar of language will affect the mastery of language skills (Effendy, Rokhyati, Rahman, Rakhmawati, \& Pertiwi (2017). Moreover, grammar is beneficial for English learners 
because incorrect use or lack of understanding of grammar might hinder communication either in speaking, writing, listening, or reading (Savage, Bitterlin, \& Price, 2010). Thus, grammar has an important role in learning English to enhance students become effective speakers.

Considering the main goal of English grammar learning, some researchers believe that enhancing learner's grammatical awareness leads to several functions. English students require a good grasp of grammatical awareness to help them develop the target language (Shuib, 2009). Then, awareness and understanding on how a structure works helps many students formulate how to say what they mean (Azar, 2007). It can be concluded that having a grammatical awareness plays a pivotal role in English grammar learning.

Despite the high importance of having grammatical awareness among English learners, in fact, many students still have lack of grammatical awareness in learning English. In the line with this, Han and Kim (2017) claimed that EFL learners have lack of grammatical awareness and they have a low proficiency level. Some students did not know the correct grammatical features due to lack of knowledge and grammatical competency (Refnita, 2014). Then, Andrews (1994) revealed that more than 50\% trainees having inadequate grammatical awareness/ knowledge. Thus, several studies reveal that student still lack of grammatical awareness.

Some researchers had already conducted similar studies to our current study. For example, Han and Kim (2017) who found that there was a significant difference in score of tense, article, and voice for grammatical awareness between high level and low-level groups. Both of groups had a high score for category of voice while they had low scores for vocabulary and morphology and perceived difficulties of articles and voice. Additionally, a study done by Shuib (2009) revealed that whole participants who did not perform well in test were in a low level of awareness of grammatical knowledge. Also Andrews (1994) found that more than $50 \%$ of trainees had an inadequate grammatical awareness/ knowledge. This study was aimed to find out the student teachers' grammatical awareness and their perception towards grammatical awareness.

\section{Literature Review}

\subsection{The Role of Grammar in Adult ESL}

English grammar is one of English competences consisting of system of a language which is must be comprehended and mastered by English language students. According to Greenbaum and Nelson (2002), grammar refers to the set rules that allow us to combine words in our language into larger units. The awareness of need for grammar teaching should be the emphasis on English learning especially among the teachers who use grammar instruction in the language classrooms. According to Savage et al. (2010), there are three roles that underline the importance of grammar in learning English. They are grammar as an enabling skill and grammar as a means to self- sufficiency. First, grammar is a necessary master skill that enables competence to develop in the area of listening, speaking, reading, and writing. When grammar is incorrect or misunderstood in any of these areas, communication may be disrupted. Second, grammar is essential to acquire a new language. The last, grammar is self-sufficiency. Students need to understand of grammatical structures as they listen to lectures and read manual and textbooks as well as to use the forms correctly when they make oral presentations and write papers. Moreover, the ability to self-correct leads to self-sufficiency. Regardless of their proficiency level or goals, almost all students can have benefits from learning English grammar.

\subsection{Grammatical Awareness}

Grammatical awareness is ability to detect a grammatical error. According to Tunde (2007), grammatical awareness refers to focus attention on the grammatical structure to words order correction ungrammatical sentences. For this study, Andrews' (1999) concept of grammatical awareness was used as the theoretical framework. This theory of grammatical awareness is divided into four types (metalanguage recognition, metalanguage production, identification and grammatical error correct correction, and grammatical rules explanation) (as cited in Shuib, 2009). The first type is the ability to recognize metalanguage. The second type is the ability to produce appropriate metalanguage terms. The third type 3 is the ability to identify and correct errors. The last type is the ability to explain grammatical rules. Each type focuses on a diverse aspect of explicit knowledge of grammar and grammatical terminology. First type is concerned with the identification of grammatical categories such as pronoun, noun, and verb. Second type focuses on the production of appropriate meta-linguistic terms involving the capability to provide grammatical terms of a given word/ phrase. Third type refers to identification and correction of errors, dwelling on the ability to recognize and correct faulty sentences or parts of sentences. The last type focuses on grammatical rules governing the use of grammar, especially during provision of input.

Grammatical awareness has some characteristics. According to Andrews (1994), there are twelve characteristics of grammatical awareness; knowledge of grammatical terminology, understanding of the concepts associated with terms, awareness of meaning/language in communication, ability to reflect on language and analyze language forms, ability to select/grade language and break down grammar points for teaching purposes, ability to analyze grammar from learners' perspective, ability to 
anticipate learners' grammatical difficulties, ability to deal confidently with spontaneous grammar questions, ability to think on one's feet in dealing with grammar problems, ability to explain grammar to students without complex metalanguage, awareness of 'correctness' and ability to justify an opinion about what is acceptable usage and what is not, and sensitivity to language/awareness of how language works

\subsection{Grammatical Metalanguage}

Metalanguage is the language used to describe a language. Metalanguage consists of grammatical terms (Purpura, 2004). According to Celce-Murcia and Larsen-Freeman (1999), three level of grammar are sub-sentential terminology, sentential terminology and supra-sentential terminology.

\subsubsection{Sub-sentential Terminology}

1. Nouns the name of a person, place, or thing. For example: The dog chased its tail.

2. Verbs a word or group of words that express action. There are four inflections can be used with English verbs:
a. $-S$ third person singular present tense verb, for example: Sue jogs every day.
b. $\quad-e d$ of past tense verbs, for example: She jogged yesterday.
c. - en of past participle, for example: He has seen the movie three times already.
d. -ing of the present participle, for example: I am teaching three courses this term.

3. Adjective a word that gives more information about a noun or pronoun (describes, modifies, identifies, or limits), for example: The old bucket sprang a leak.

4. Adverb refers to any element in a sentence used to modify a verb, adjective, another adverb, or even an entire clause, for example: Soon Rachel will retire.

5. Pronouns a word that is used to as substitute for a noun, for example, I, You, We, They.

6. Determiner a structure class word that marks or signals a noun, appearing as the first word in a noun phrase, before the noun and before any modifiers in the phrase.

There are two categories of determiners. They are:

a) Definite article is the. the is used before a noun when something or somebody specific; person, place, or thing. e. g., the book, the cat

b) Indefinite article is to identify nonspecific or generic people, places, or things. There are two types of the indefinite article: $\underline{a}$ and $\underline{\text { an. }}$. e.g. $\underline{a}$ book, a house and an essay, an umbrella.

7. Preposition is used to express the relationship of a noun or pronoun (or another grammatical element functioning as a noun) to the rest of the sentences, for example, in, out, by, at, with.
8. Conjunction a word that joins one part (word, phrase, or clause) of a sentence to another part of a sentences such as and, although.

\subsubsection{Sentential Terminology}

1. Simple sentence contains at least one subject and one verb and can stand alone as in independent Clues. For example, They are still friends.

2. Compound sentence consists of two or more clauses of equal grammatical importance. For example, $\mathrm{He}$ went to the part, but I stayed home.

3. Complex sentence contains a main clause and one or more dependent clause, for example, Peggy frequently calls because she wants to stay in touch.

\subsubsection{Supra-sentential Terminology}

Cohesion is grammatical and semantic connections between sentences and paragraphs. The classification of grammatical cohesion is divided into four subclasses; reference, substitution, ellipsis and conjunction.

a. Reference: The boy wanted a new bike. One day, he... (he refers the boy)

b. Ellipsis: A: Who wrote the letter?

B: Marty. (The response Marty elliptically signals that Marty wrote the letter).

c. Substitution: I plan to enter college next year. If I do... (do substitutes for enter college)

d. Conjunction: Peter needed some money. He, therefore, decided to get a job (therefore makes explicit the clausal correlation between the first and second sentences).

\section{Methods}

\subsection{Research Design}

In this study, a mixed method was applied. According to Creswell (2005), a mixed method research design is the procedures for collecting both quantitative and qualitative data in a single study and for analyzing and reporting the data based on priority and sequence of the information. The present study, the quantitative method was used to determine students' grammatical awareness while the qualitative method was used to find out student teacher's perception towards grammatical awareness.

\subsection{Research Site and Participants}

The total number of participants in this study was 133 taken by using the purposeful sampling technique from 463 active student teachers of English Education Study Program at one State Islamic University in Indonesia. Four participants did not come for the test during the study, so the total number of participants was 129 . To obtain the quantitative data, the characteristics of choosing the 
participants were they had already taken all grammar courses. In addition, the purposeful sampling technique was used to get participants in the qualitative data. The participants were the students who had low, moderate, and high levels of grammatical awareness of the test results. There were 12 student teachers.

\subsection{Data Collection and Analysis}

The data of this study were collected through a grammatical awareness test and a semi-structured interview. The grammatical awareness test was developed by Schoonmaker (2015) consisting of 48 items of grammatical awareness assessing various facets of grammatical awareness. The test consists of four tasks. Task 1 was designed to measure respondents' ability to recognize metalanguage. Task 2 was administered to measure their ability to produce appropriate metalanguage terms. Task 3 was to find out their ability to identify and correct errors, whereas task 4 was conducted to measure their ability to explain grammatical rules. For the validity and reliability, the validity of the grammatical awareness test was administrated to 128 of pre-service teachers. Those participants had the same level and characteristics as the participants in this study. For the reliability, the grammatical awareness test was reliable, since Cronbach Alpha score was 0.89 .

The grammatical awareness test was used to look at the student teachers' grammatical awareness. This test consisting of 48 item of grammatical awareness including: metalanguage recognition, metalanguage production, identification and grammatical errors correction, and grammatical rules explanation. Participants were given 20-30 minutes to fill out the test. In this study, we also used semi-structured interviews to obtain information about student teachers' perception towards grammatical awareness. There were three questions of the interview. We did the interview with face-to-face and lasted for about 20 30 minutes in each participant. The interview was held 3 hours after the completion of the grammatical awareness test.

\subsection{Data Analysis}

In analyzing the quantitative data, we followed steps proposed by Creswell (2005). First, the result of the grammatical awareness test was checked by a mark scheme (scoring guidelines). In section 1 , part 1 and part 2, each of correct answers got a score of "2", while incorrect answer/ no answer got a "0" score. For section 2, in part 1, each correct answer got a score of " 1 " and incorrect answer got a score of " 0 ". Part 2, the full correction explanation got a score of "2." Partially, the correct explanation got a score of " 1 " and the incorrect explanation got a score of "0."

Second, we used the statistical package for social and science (SPSS) version 23 to analyze the data from the grammatical awareness test. We used a mean and standard deviation to determine student teachers' level of grammatical awareness. Participants were categorized at the high level if they got a score between 51-81. For the moderate level if the score were 31-51, and for the low level if the score were $0-31$. In addition, we made a percentage of each correct item was answered by participants on grammatical awareness test.

For the qualitative data, after the data of interview were obtained, the data were analyzed by using thematic analysis (Creswell, 2012). First, we put the data into computer, after that we listened to the audio recorder and then transcribed them. Second, we read the transcription and started to code the data related to research questions. A list of statements was used to classify the answers of each interviewee in terms of student teachers' perception towards grammatical awareness.

\section{Findings}

\subsection{The Quantitative Results: The Grammatical Awareness Test}

The total participants of English Education Study Program were 133 student teachers. However, there were only 129 student teachers participated in this study; four participants were not present.

This section provides the findings of the data analysis concerning student teachers' grammatical awareness. The data were analyzed through SPSS. The student teachers' grammatical awareness was determined by the analysis of the results of the grammatical awareness test. The test consists of 48 questions and is divided into 4 parts; each part consisting of several items:

1. Metalanguage recognition consisting of 14 categories of the grammatical awareness test.

2. Metalanguage production consisting of 4 categories of the grammatical awareness test.

3. Identification and grammatical error correction (correct faulty sentences) consisting of 15 sentences error of the grammatical awareness test.

4. Grammatical rules explanation (grammatical error explanation) consisting of 15 items of the grammatical awareness test.

The results of grammatical awareness test proposed by Andrews (1999) could be seen in the following table.

\subsubsection{Metalanguage Recognition}

The first type of grammatical awareness is related to respondents' ability to recognize metalanguage. Table 1 , for the verb items, it shows that $96.1 \%$ or 124 student teachers answered correctly indicating that 124 student teachers were able to identify verbs. Most of them labeled "are" and "delivered" as verbs. For the auxiliary verb items, it shows that $55 \%$ or 71 student teachers answered 
correctly. Also, 71 student teachers answered correctly. It was surprising that 58 of 129 student teachers failed to identify "are" as an auxiliary verb, most of them labeled "are delivered" as an auxiliary verb. For the participle verb items, it shows that $58.9 \%$ or 76 student teachers answered correctly showing that 53 of 129 student teachers were unable to identify the participle verb "delivered". For the infinitive verb items, it shows that $53.5 \%$ or 69 student teachers answered correctly. It meant that student teachers faced difficulties when they identified infinitive verbs. As an indication of the difficulties, many of student teachers labels "are" "delivered", " has" and "have" as infinitive verba.

Table 1. Percentage of the correct answers by participants

\begin{tabular}{|c|c|c|c|}
\hline No & Item & Frequency & Percentage \\
\hline 1 & $\begin{array}{c}\text { Verb } \\
\text { (are, delivered, has, happens, } \\
\text { have, to have) }\end{array}$ & 124 & $96.1 \%$ \\
\hline 2 & $\begin{array}{c}\text { Auxiliary Verb } \\
\text { (are) }\end{array}$ & 71 & $55 \%$ \\
\hline 3 & $\begin{array}{c}\text { Participle Verb } \\
\text { (delivered) }\end{array}$ & 76 & $58.9 \%$ \\
\hline 4 & $\begin{array}{c}\text { Infinitive Verb } \\
\text { (to have) }\end{array}$ & 69 & $53.5 \%$ \\
\hline 5 & $\begin{array}{c}\text { Noun } \\
\text { (materials, factory, supplier, } \\
\text { knowledge, contact) }\end{array}$ & 124 & $96.1 \%$ \\
\hline 6 & $\begin{array}{c}\text { Countable Noun } \\
\text { (materials, factory, supplier, } \\
\text { contacts) }\end{array}$ & 120 & $93 \%$ \\
\hline 7 & $\begin{array}{c}\text { Uncountable Noun } \\
\text { (knowledge) }\end{array}$ & 105 & $81.4 \%$ \\
\hline 8 & $\begin{array}{l}\text { Relative Pronoun } \\
\text { (who) }\end{array}$ & 112 & $86.8 \%$ \\
\hline 9 & $\begin{array}{c}\text { Adjective } \\
\text { (technical, right) }\end{array}$ & 97 & $75.2 \%$ \\
\hline 10 & $\begin{array}{l}\text { Article: Definite } \\
\text { (the) }\end{array}$ & 88 & $68.2 \%$ \\
\hline 11 & $\begin{array}{l}\text { Article: Indefinite } \\
(a)\end{array}$ & 85 & $65.9 \%$ \\
\hline 12 & $\begin{array}{c}\text { Adverb } \\
\text { (usually, no) }\end{array}$ & 72 & $55.8 \%$ \\
\hline 13 & $\begin{array}{l}\text { Preposition } \\
\text { (to, by) }\end{array}$ & 113 & $87.6 \%$ \\
\hline 14 & $\begin{array}{c}\text { Conjunction } \\
\text { (But) }\end{array}$ & 121 & $93.8 \%$ \\
\hline
\end{tabular}

For the noun items, it shows that $96.1 \%$ or 124 student teachers answered correctly. It meant that only 5 of 129 student teachers failed to identify nouns of "materials", "factory", "supplier", "knowledge" and "contacts". For the countable noun items, it shows that $93 \%$ or 120 student teachers answered correctly. It meant that, which only 9 of 129 student teachers failed to identify "materials", "factory", "supplier" and "contacts" as countable nouns. For the uncountable noun items, it shows that $81.4 \%$ or 105 student teachers answered correctly. It meant that student teachers were able to identify "knowledge" as an uncountable noun. For the relative pronoun items, it shows that $86.8 \%$ or 112 student teachers answered correctly. It meant that most of student teachers were correctly to identify "who" as a relative pronoun. For the adjective items, it shows that $75.2 \%$ or 97 student teachers answered correctly. It meant that 97 student teachers were able to identify the adjectives of "technical" and "right".

For the definite article and indefinite article items, it shows that $68.2 \%$ or 88 and $65.9 \%$ or 85 student teachers answered correctly. It meant that 41 and 44 of 129 student teachers failed to identify "the" and " $a$ " as definite and indefinite articles. It was probable that the errors on these items were misleading because student teachers were wrong to determine which were the definite and indefinite articles. For the adverb items, it shows that $55.8 \%$ or 72 student teachers answered correctly. It was surprising that 57 of 129 student teachers failed to identify the adverb of "usually.. For the preposition items, it shows that $87.6 \%$ or 113 student teachers answered correctly. It meant that most of student teachers were well performed to identify " $t o$ " and " $b y$ " as prepositions. For the conjunction items, it shows that $93.8 \%$ or 121 student teachers answered correctly. It meant that only 8 of 129 the student teachers did not identify the preposition of " $b u t$ ".

\subsubsection{Metalanguage Production}

As shown in Table 2, for the subject items, it shows that $86 \%$ or 111 student teachers answered correctly suggesting that 111 of 129 student teachers were able identify the subject of given sentences. They chose the headword "Joe", in accordance with the traditional type of analysis, rather than chose "Poor little Joe" (noun phrase). For the predicate items, it shows that $93 \%$ or 120 student teachers answered correctly and only $7 \%$ failed to answer correctly. It meant that most of student teachers identified the predicates of "has, or "has nowhere to shelter" in the sentence as the easiest item rather than other items. For the direct object items, it shows that $57.4 \%$ or 74 student teachers answered correctly. It meant that the direct object of "Joe" in the sentence was missed by 55 of 129 student teachers. It was considered as the most difficult ones. For the indirect object items, it shows that $64.3 \%$ or 83 student teachers answered correctly and only $35.7 \%$ made errors. It meant that 83 of 129 student teachers were able to identify the indirect object of "him "of a simple sentence.

Table 2. Percentages of the correct answers by participants

\begin{tabular}{cccc}
\hline No & Item & Frequency & Percentage \\
\hline 1 & $\begin{array}{c}\text { Subject } \\
\text { (Joe or Poor little Joe) }\end{array}$ & 111 & $86 \%$ \\
\hline 2 & $\begin{array}{c}\text { Predicate } \\
\text { (has } \text { or has nowhere to shelter) }\end{array}$ & 120 & $93 \%$ \\
\hline 3 & $\begin{array}{c}\text { Direct Object } \\
(\text { Joe })\end{array}$ & 74 & $57.4 \%$ \\
\hline 4 & $\begin{array}{c}\text { Indirect Object } \\
\text { (him) }\end{array}$ & 83 & $64.3 \%$ \\
\hline
\end{tabular}


Table 3. Percentages of the correct answers by participants

\begin{tabular}{|c|c|c|c|c|}
\hline No. Item & Question on Test & The Correct Sentence & Frequency & Percentage \\
\hline 1 & I walk to work very quick. & I walk to work very quickly. & 86 & $66.7 \%$ \\
\hline 2 & $\begin{array}{l}\begin{array}{l}\text { When her said that, Jack hit } \\
\text { her. }\end{array} \\
\text {. }\end{array}$ & $\begin{array}{l}\text { When she/he said that, Jack hit her. or Jack hit } \\
\text { her when she said that. }\end{array}$ & 107 & $82.9 \%$ \\
\hline 3 & $\begin{array}{l}\text { Every day I am making good } \\
\text { resolutions. }\end{array}$ & Every day I make good resolutions. & 93 & $72 \%$ \\
\hline 4 & $\begin{array}{l}\text { She's the taller of the four } \\
\text { sisters. }\end{array}$ & She's the tallest of the four sisters. & 49 & $38 \%$ \\
\hline 5 & $\begin{array}{l}\text { I live in a room at a top of an old } \\
\text { house. }\end{array}$ & I live in a room at the top of an old house. & 52 & $40.3 \%$ \\
\hline 6 & $\begin{array}{l}\text { Mommy goed to the park } \\
\text { yesterday. }\end{array}$ & Mommy went to the park yesterday. & 89 & $69 \%$ \\
\hline 7 & The children put on their coat. & The children put on their coats & 56 & $43.4 \%$ \\
\hline 8 & $\begin{array}{l}\text { He usually like to study at the } \\
\text { library. }\end{array}$ & He usually likes to study at the library & 74 & $57.4 \%$ \\
\hline 9 & $\begin{array}{l}\text { I don't like people which are } \\
\text { always apologizing. }\end{array}$ & $\begin{array}{l}\text { I don't like people who are always apologizing. } \\
\text { or I don't like people that are always } \\
\text { apologizing. }\end{array}$ & 62 & $48.1 \%$ \\
\hline 10 & $\begin{array}{l}\text { I opened the door, but I couldn't } \\
\text { see nobody. }\end{array}$ & $\begin{array}{c}\text { Iopened the door, but I couldn't see anybody or } \\
\text { anyone. or I opened the door, but I could see } \\
\text { nobody. }\end{array}$ & 25 & $19.4 \%$ \\
\hline 11 & $\begin{array}{l}\text { When I was a small baby I have } \\
\text { earaches. }\end{array}$ & $\begin{array}{c}\text { When I was a small baby, I had earaches or } \\
\text { When I was a small baby, I used to have } \\
\text { earaches }\end{array}$ & 70 & $54.3 \%$ \\
\hline 12 & I will pick up you later. & I will pick you up later. & 93 & $72.1 \%$ \\
\hline 13 & $\begin{array}{l}\text { Josh and Pete have went to the } \\
\text { show. }\end{array}$ & Josh and Pete have gone to the show. & 68 & $52.7 \%$ \\
\hline 14 & Give the paper to Joe and $\underline{\mathrm{I}}$. & $\begin{array}{c}\text { Give the paper to Joe and me or me and Joe. or } \\
\text { Give the paper to us. or } \\
\text { Give us the paper. }\end{array}$ & 98 & $76 \%$ \\
\hline 15 & $\begin{array}{l}\text { She has called a few minutes } \\
\text { ago. }\end{array}$ & She called a few minutes ago. & 43 & $33.3 \%$ \\
\hline
\end{tabular}

\subsubsection{Identification and Grammatical Error Correction}

The third type is related to respondents' ability to identification and grammatical error correction.

For item 1, it shows that $66.7 \%$ or 86 student teachers answered correctly. It meant that 86 of 129 student teachers were able to correct sentence errors about "adverb (quickly)". For item 2, it shows that $82.9 \%$ or 107 student teachers answered correctly. It proved that they were able to identify the sentence errors about "subject and object pronouns (she/he)". For item 3, it shows that $72 \%$ or 93 student teachers answered correctly. It meant that most of them were able to identify sentence errors about "present tense (makes)". For item 4 , it shows that $38 \%$ or 49 student teachers answered correctly. It meant that over half of student teachers weren ot able to identify errors in terms of "degree of comparison (tallest)". For item 5, it shows that $40.3 \%$ or 52 student teachers answered correctly. Based on the result, 77 of 129 student teachers failed to identify sentence errors about "indefinite articles (the)".

For item 6, it shows that $69 \%$ or 89 student teachers answered correctly. It meant that most of student teachers were able to identify errors about "irregularity verb (went)" in the sentence. For item 7, it shows that $43.4 \%$ or 56 student teachers answered correctly. Based on that result, over half of student teachers had a poor performance to identify and correct sentence errors about "plural of noun (coats)". For item 8 , it shows that $57.4 \%$ or 74 student teachers answered correctly. It meant that 74 of 129 student teachers answered incorrectly about "subject-verb agreement (likes)". For item 9, it shows that $48.1 \%$ or 62 student teachers answered correctly showing that 76 of 129 student teachers failed to identify and correct sentence errors about "relative pronoun (who/that)". For item 10, it shows that $19.4 \%$ or 25 student teachers answered correctly. It meant that 104 of 129 student teachers were unable to identify error and correct sentence errors about "double negative sentence as ungrammatical sentence (anybody/anyone)". The high error rate on this item was due to the majority of student teachers gave wrong answers.

For item 11, it shows that $54.3 \%$ or 60 student teachers answered correctly. Based on the result, over half student teachers were able to identify and correct sentence errors about "simple past tense (had/used to have)". For item 12, it shows that $72.1 \%$ or 93 student teachers answered correctly. It meant that 36 of 129 student teachers failed to identify and correct sentence errors about "phrasal verb (pick-up)". For item 13, it shows that $52.7 \%$ or 68 student teachers answered correctly suggesting that half of student 
teacher answered incorrectly on sentence errors about "simple perfect tense (gone)". For item 14, it shows that $76 \%$ or 98 student teachers answered correctly. It meant that over half of student teachers were able to identify and correct sentence error about "pronouns (me/us)". For item 15 , it shows that $33.3 \%$ or 43 student teachers answered correctly. It was surprising that 86 of 129 student teachers were unable to correct faulty sentences about "simple past tense (called)".

\subsubsection{Grammatical Rules Expalation}

The fourth type is related to the explanation of grammatical rules.

Table 4. Percentage of the correct answers by participants

\begin{tabular}{ccccc}
\hline \multirow{2}{*}{$\begin{array}{c}\text { Item } \\
\text { Number }\end{array}$} & \multicolumn{2}{c}{ Partially Explanation } & \multicolumn{2}{c}{ Fully Explanation } \\
\cline { 2 - 5 } & Frequency & Percentage & Frequency & Percentage \\
\hline Item 1 & 37 & $28.7 \%$ & 4 & $3.1 \%$ \\
\hline Item 2 & 53 & $41.1 \%$ & 3 & $2.3 \%$ \\
\hline Item 3 & 62 & $48.1 \%$ & 21 & $16.3 \%$ \\
\hline Item 4 & 17 & $13.2 \%$ & 3 & $2.3 \%$ \\
\hline Item 5 & 26 & $20.2 \%$ & 4 & $3.1 \%$ \\
\hline Item 6 & 71 & $55 \%$ & 12 & $9.3 \%$ \\
\hline Item 7 & 15 & $11.6 \%$ & 2 & $1.6 \%$ \\
\hline Item 8 & 45 & $34.9 \%$ & 6 & $4.7 \%$ \\
\hline Item 9 & 24 & $18.6 \%$ & 14 & $10.9 \%$ \\
\hline Item 10 & 15 & $11.6 \%$ & 2 & $1.6 \%$ \\
\hline Item 11 & 26 & $20.2 \%$ & 5 & $3.9 \%$ \\
\hline Item 12 & 34 & $26.4 \%$ & 2 & $1.6 \%$ \\
\hline Item 13 & 55 & $42.6 \%$ & 2 & $1.6 \%$ \\
\hline Item 14 & 46 & $35.7 \%$ & 2 & $1.6 \%$ \\
\hline Item 15 & 32 & $24.8 \%$ & 4 & $3.1 \%$ \\
\hline
\end{tabular}

From Table 4 , on item 1, it could be seen that $28.7 \%$ or 37 and $3.1 \%$ or 4 student teachers had a poor performance to explain rules about differences between "adverb" and "adjective". It meant that 37 student teachers were able to explain grammatical errors partially correctly while 4 of them explained fully correctly. For item 2 , it could be seen that $41.1 \%$ or 53 and $2.3 \%$ or 3 student teachers answered partially and fully correctly. It meant that 53 student teachers were able to explain the rules about "subject" and "object pronoun" (partially correct explanation), while only 3 student teachers were able to explain it (fully correct explanation). For item 3 , it could be seen that $48.1 \%$ or 62 and $16.3 \%$ or 21 student teachers answered partially and fully correctly. It meant that 62 student teachers were able to explain partially correctly the rules of "simple present tense" and 21 student teachers explained fully correctly.

For item 4 , it could be seen that $13.2 \%$ or 17 and $2.3 \%$ or 3 student teachers answered partially and fully correctly. It proved that most of student teachers had difficulties to explain grammatical rules regarding "comparing thing/people". For item 5, it could be seen that $20.2 \%$ or 26 and $3.1 \%$ or 4 student teachers answered partially and fully correctly. It was surprising that 103 student teachers were not able to explain grammatical rules about "indefinite article" correctly in the sentence. For item 6 , it could be seen that $55 \%$ or 71 and $9.3 \%$ or 12 student teachers answered partially and fully correctly. It meant that 71 of 129 of student teachers were able to explain grammatical rules in partially correctly about "irregular verb go" but only some of them were able to answer fully correctly.

On item 7 , it could be seen that $11.6 \%$ or 15 and $1.6 \%$ or 2 student teachers answered partially and fully correctly indicating that student teachers had poor performances to explain rules about relationship between "subject" and "direct "object" (agreement). For item 8, it could be seen that $34.9 \%$ or 45 and $4.7 \%$ or 6 student teachers answered partially and fully correctly. Based on that result, 78 student teachers gave wrong answers when they explained these sentence errors about "subject-verb agreement". For item 9 , it could be seen that $18.6 \%$ or 24 and $10.9 \%$ or 14 student teachers answered partially and fully correctly indicating that most of student teachers were unable to explain grammatical rules in sentence error about "relative pronoun who/that".

For item $10,11.6 \%$ or 15 and $1.6 \%$ or 2 student teachers answered partially and fully correctly. It was also more surprising that almost all of student teachers gave wrong answers when they explained grammatical rules in the sentence error about "double negative issue as ungrammatical in standard English". For item 11, 20.2\% or 26 and $3.9 \%$ or 5 student teachers answered partially and fully correctly. Also, 99 of 129 student teachers answered incorrectly when they explained the rules about "simple past tense". On item 12 , it could be seen that $26.4 \%$ or 34 and $1.6 \%$ or 2 student teachers answered partially and fully correct explanation indicating that some of students teacher were able to explain the rules in the sentence error about "separable phrasal verb."

For item $13,43 \%$ or 55 and $2 \%$ or 2 student teachers answered partially and fully correctly. 55 student teachers were able to explain grammatical rules about "present perfect tense", whereas only 2 student teachers were able to explain fully correctly. For item $14,35.7 \%$ or 45 and $1.6 \%$ or 2 student teachers answered partially and fully correctly indicating that 45 student teachers were able to explain the rules for "subject" or "object pronoun" correctly. For item $15,24.8 \%$ or 32 and $3.1 \%$ or 4 student teachers answered partially and fully correctly showing that 63 of 129 student teachers gave wrong answers when they explained grammatical rules about "simple past tense and present perfect tense".

\subsection{Result of Overall Scores}

Table 5 presents the descriptive summary of results 
Table 5. Mean of score for overall test

\begin{tabular}{cccccc}
\hline & N & Minimum & Maximum & Mean & $\begin{array}{c}\text { Std. } \\
\text { Deviation }\end{array}$ \\
\hline Overall & 129 & 15 & 56 & 41,28 & 9,492 \\
\hline
\end{tabular}

As could be seen, the result of the test was quite disappointing. None of the student teachers answered all the test items correctly. The highest percentage was 56 and the lowest was 15 . The mean score for overall test was 41.39. Their performance could be said to be only at the moderate level. Furthermore, Table 5 shows the level of student teachers' grammatical awareness. The details are as follows.

Table 6. Range of mean scores for overall test

\begin{tabular}{ccc}
\hline Range & Frequency & Percentage \\
\hline $15-20$ & 4 & $3.1 \%$ \\
\hline $21-25$ & 5 & $3.9 \%$ \\
\hline $26-30$ & 9 & $7 \%$ \\
\hline $31-35$ & 18 & $14 \%$ \\
\hline $36-40$ & 14 & $10.8 \%$ \\
\hline $41-45$ & 24 & $18.6 \%$ \\
\hline $46-50$ & 37 & $28.7 \%$ \\
\hline $51-56$ & 18 & $14 \%$ \\
\hline Total & 129 & $100 \%$ \\
\hline
\end{tabular}

Nevertheless, the majority of the participants (72\%) were in the range between $31-50$. It could be seen in Table 6 . It suggests that in spite of the large variation of scores, most participants were at the moderate level. Those whose scores above 50 constitutes $14 \%$ of the total, whereas those scored less than 30 constitutes $14 \%$ of the sample. Clearly, it could be concluded that the student teachers were deficient in grammatical awareness. There were also variations in the mean scores among the four parts as displayed in table 7 .

Table 7. Mean scores for each task

\begin{tabular}{ccccc}
\hline Parts & Minimum & Maximum & Mean & $\begin{array}{c}\text { Std. } \\
\text { Deviation }\end{array}$ \\
\hline $\begin{array}{c}\text { Metalanguage } \\
\text { recognition } \\
(18 \text { items })\end{array}$ & 6 & 28 & 21,35 & 5,007 \\
\hline $\begin{array}{c}\text { Metalanguage } \\
\text { production } \\
(4 \text { items })\end{array}$ & 2 & 8 & 6,02 & 1,879 \\
\hline $\begin{array}{c}\text { Error } \\
\text { correction } \\
(15 \text { items })\end{array}$ & 1 & 14 & 8,26 & 3,163 \\
\hline $\begin{array}{c}\text { Rules and } \\
\text { explanations } \\
(15 \text { items })\end{array}$ & 0 & 15 & 5,66 & 3,532 \\
\hline
\end{tabular}

As could be seen from the table, the mean score for metalanguage recognition was 21.35 , the mean score of metalanguage production was 6.02 , identification and grammatical error correction was 8.26 and grammatical rules explanation was 5.66. Evidently, it could be said that metalanguage recognition was the easiest part for the participants. Then, it was followed by identification and grammatical error correction and metalanguage production. Rules and explanations were proved to be the most difficult part for the participants.

\subsection{The Results of the Interview}

The interviews were conducted after participants were given the grammatical awareness test. There were three questions to be answered by 12 (twelve) student teachers.

1. In understanding of English grammar, "what student teachers thought about their understanding perceptions of English grammar and how they rated about their understanding of English grammar".

2. In aspects of English grammar, "what student teachers view about aspects of English grammar which are difficult to them, which the aspects of English grammar are the easiest and most difficult ones".

3. In possible causes of English grammar difficulties, "what student teachers thought about the possible causes of their English grammar difficulties".

After conducting the interviews, we found some opinions about grammatical awareness. The themes and codes gained from thematic analysis are listed in table 8 .

Table 8. Themes and codes for the student teacher's perception towards grammatical awareness

\begin{tabular}{|c|c|}
\hline Themes & Codes \\
\hline $\begin{array}{l}\text { Understanding of } \\
\text { English grammar }\end{array}$ & $\begin{array}{l}\text { A. Almost of respondents argued that } \\
\text { understanding of English grammar was } \\
\text { important. } \\
\text { B. a small number of respondents } \\
\text { admitted that understanding of English } \\
\text { grammar was difficult. } \\
\text { C. Almost of interviewees admitted that } \\
\text { they were sufficient of understanding } \\
\text { English grammar } \\
\text { D. The most interviewees argued that } \\
\text { they lacked of understanding of English } \\
\text { grammar }\end{array}$ \\
\hline $\begin{array}{l}\text { Aspect of English } \\
\text { grammar }\end{array}$ & $\begin{array}{l}\text { A. Almost of student teacher argued that } \\
\text { explain grammatical rules as the } \\
\text { difficulties part. } \\
\text { B. The most of student teacher stated } \\
\text { that metalanguage production as the } \\
\text { easiest part. }\end{array}$ \\
\hline $\begin{array}{l}\text { Possible causes of } \\
\text { English grammar } \\
\text { difficulties }\end{array}$ & $\begin{array}{l}\text { A. All of interviewees stated that causes } \\
\text { of English grammar difficulties were } \\
\text { grammar rules, especially tenses. }\end{array}$ \\
\hline
\end{tabular}

\subsubsection{The Perception of Understanding of English} Grammar

Based on the result of interviews, it was found that four of the student teachers' stated that understanding of English grammar was important while six of them said it was difficult.

“...understanding the role of English grammar is 
important because it used in English because it related to what we say, incorrect grammar causes the meaning" (YNH, personal communication, December 12, 2018).

"I think understanding of English grammar is important because it used in English context..." (YNH, personal communication, December 12, 2018).

"I think understanding of grammar is definitely important especially in English context" (UK, personal communication, December 12, 2018).

"Understanding of English grammar is important such as in speaking and other skills" (AG, personal communication, December 12, 2018).

From those statements, it could be concluded that four participants of this study felt that understanding of English grammar was important because grammar helped them formulate how to say what they meant and led them to have their successful communication.

However, the results of the interview also revealed that five student teachers felt that understanding of English grammar was difficult. It could be seen from their answered below:

"My understanding of English grammar is not good, it because learned English grammar is too difficult". (AN, personal communication, December 12, 2018

"In think, my understanding of English grammar is lack; it is because I am difficult to explain the verb". (DS, personal communication, December 12, 2018)

"... I think it is hard to learn and understand of English grammar because grammar so complicated" (MN, personal communication, December 13, 2018).

"I think, understanding of English grammar is difficult because the rules of English grammar. Sometimes I forgot about tenses." (NA, personal communication, December 13, 2018).

"In my opinion, my understanding of English grammar is lack; I do not master grammar, in grammar so many parts" (MI, personal communication, December 13, 2018).

Thus, from student teachers' statements, it could be seen that they faced problems about English grammar in terms of the grammar rules.

Based on the second question, it was found that six of student teachers admitted that their understanding of English grammar was sufficient, but, five student teachers admitted that they lacked of understanding of English grammar. The result of the question showed that six of them thought that their understanding about English grammar was sufficient.

"That's enough" (YNP, personal communication, December 12, 2018).

"I rate the category B" (AN, personal communication, December 13, 2018).

"...In category moderate" (MM, personal communication, December 13, 2018).

"I think to rate my understanding of English grammar is enough..." (YW, personal communication, December 12, 2018).

"My understanding of English grammar is sufficient" (UK, personal communication, December 12, 2018).

"I think my understanding of grammar is classified as moderate" (KJN, personal communication, December 13, 2018).

In contrast, the result of the question also showed that five student teachers lacked of understanding of English grammar.

"My understanding of English grammar still lacked, I should learn more" (DA, Personal Communication, December 13, 2019).

"I think, still less of understanding of English grammar" (AG, Personal Communication, December 13, 2019).

"I lack understanding of English grammar" (MN, Personal Communication, December 13, 2019).

"To rate my understanding about English grammar, if compare with my friends, they more better than me" (NA, Personal Communication, December 13, 2019).

"My understanding of English grammar still lacked" (MA, Personal Communication, December 12, 2019).

From the statements above, it could be concluded that most of the student teachers were not sufficiently proficient in English grammar.

\subsubsection{The Views about Aspects of English Grammar Pose Difficulty to Student Teachers}

Based on the result of interview, seven of student teachers stated that grammatical rules were as the most difficult aspect. Seven student teachers considered metalanguage production as the easiest aspect. They admitted that it was difficult for them to explain grammatical rules in English standard.

"I usually know the sentence error but it is hard to explain the grammatical rules why the sentence is error." (YWN, Personal Communication, December 12, 2018). "...Explain grammatical rules as the most difficult part" (DA, Personal Communication, December 12, 2018).

"...explain grammatical rule being the hardest part" (ANIS, Personal Communication, December 12, 2018).

"Explain grammatical rule is the most difficult part because I lack understanding of grammar, I know the sentence error but cannot explain the rules." (AG, Personal Communication, December 12, 2019).

"I think this sentence (question in part 3) is correct, in fact the sentence is incorrect. So, when I identify the sentence error is difficult it also difficult to explain the rules why this sentence error" (NA, Personal Communication, December 13, 2018).

"I think explain grammar rules also difficult, for example, when explain the rules of tenses present continuous become present tense..." (MM, Personal Communication, December 13, 2018).

"The most difficult part is grammatical rule explanation 
because I lack understanding of English grammar" (MA, Personal Communication, December 13, 2018).

The opinions above revealed that they believed that from the four aspects of English grammar, grammatical rule explanation was the most difficult aspect. In addition, seven of student teachers considered metalanguage production the easiest aspect.

"Grammatical function is the easiest part (ANIS, Personal Communication, December 12, 2018).

"The easy aspect is part 2 (metalanguage production)" (DA, Personal Communication, December 12, 2018).

"...to produce appropriate grammatical function is easiest part (metalanguage production (AG, Personal Communication, December 12, 2019).

“...Identify such as subject and predicate as easiest" (NA, Personal Communication, December 13, 2018).

"I think from four aspects of English grammar, part 2 recognize such as noun verb, it is easy part" (MM, Personal Communication, December 13, 2018).

"...Produce appropriate grammatical function such as predicate is easy" (AG, Personal Communication, December 12, 2019).

"The easiest part is produce grammatical function such as subject and predicate (metalanguage production)" (KJN, personal communication, December 13, 2018).

"...The easiest part is produce grammatical function (metalanguage production)" (MA, Personal Communication, December 13, 2018).

From the explanation above, it could be inferred that the majority of the participants admitted that metalanguage production was the easiest aspect.

\subsubsection{Perceptions of Possible Causes of the English Grammar Difficulties}

The student teachers had different perceptions about the possible causes of difficulties in English grammar. Based on the result of interviews, ten of student teachers stated that the possible cause was the complexity of rules in English grammar.

"Because in English grammar there many rules in English grammar such as simple past tense, and present continuous. I felt difficult about it. Therefore, I need more to learn more become understand about it. Besides, there are also passive and active voices. It made me confused to use the formulas of it. English grammar is complicated rules". (NF, Personal Communication, December 13, 2018).

"I felt difficult to distinguish regular and irregular verb". (KJN, Personal Communication, December 13, 2018).

"I lack understanding about English grammar, especially tenses. There are 16 tenses and all of the tenses I do not memorize all. For example, in writing class, I got assignment to write in present continuous. In this part, I felt confused about the rules of tense". (MN, MM, AN Personal Communication, December 13, 2018).
"I confused about the rules of tense about continuous and past perfect tenses". (NA, Personal Communication, December 13, 2018).

"I do not really understand about the rules of tenses". (AG, Personal Communication, December 12, 2018).

"I have not mastered the rules of the structure". (DA, NA Personal Communication, December 13, 2018).

"I feel difficult to determine which regular and irregular verb" (YWH, YW, Personal Communication, December 12, 2019)

From the responses above, student teachers' difficulty of grammar rules was tenses.

\section{Discussion}

\subsection{The Discussion about the Student Teachers' Grammatical Awareness}

There were four types of grammatical awareness which were able to be recognized. They were metalanguage, produce appropriate metalanguage terms, identify and grammatical errors correction, and grammatical rules explanation.

The finding of the study indicated that the mean of score among tasks given were: metalanguage recognition (21.35), metalanguage production (6.02), identification and grammatical error correction (8.26), and grammatical rules explanations (5.66). Based on the mean scores, metalanguage recognition was the highest score. It meant that the whole participants had good performance of this task. The finding of the study was consistent with the findings of other EFL/ESL studies (Andrews, 1994; Shuib, 2009). Andrews (1994) found that Hong Kong secondary school English teachers had good performance in testing their understanding and ability to apply grammatical terms correctly (metalanguage recognition). Also, Shuib (2009) found that among four types of grammatical awareness, metalanguage recognition task was the easiest and rules and explanation task were the hardest. It meant that the primary school English teachers were able to recognize metalanguage in the sentence, but they failed to explain grammatical rules.

Furthermore, the majority of student teachers were able to identify grammatical recognition task. This task consists of 14 items "verb, noun, countable noun, uncountable noun, relative pronoun, definite article, indefinite article, adjective, preposition, conjunction, auxiliary verb, participle verb, infinitive verb and adverb." It is in line what Cajkler and Hislam (2002) said that trainee teachers ranked low rating regarding recognition of word classes (grammatical metalanguage), for instance noun, verb, adverb, conjunction and preposition. It caused misconception of label names of parts of speech. In addition, Han and Kim (2011) found that Korean University level noted that articles seemed to be the most 
difficult to utilize in the perception test. It made them unfamiliar with articles as they did not exist in their first language.

The findings in this study also demonstrated that most of the items in rules and explanation part were answered incorrectly. Even, some of them did not give their answers. Almost all the participants either gave incorrect explanations or provided a blank response. Andrews (1999) claimed that the metalanguage recognition is cognitively less demanding than metalanguage production part and rules and explanation part. The metalanguage production task adds to the cognitive burden by requiring subjects to look within their own mental store of explicit knowledge about language in order to seek the appropriate metalinguistic terms to describe a language item. The rules and explanation part are cognitively demanding as it requires respondents to:

1. reflect upon a grammatical error which they have corrected,

2. make explicit the rule which has been broken, and

3. employ appropriate metalanguage in order to explain the rules.

In order to highlight the level of student teachers' grammatical awareness, mean scores for overall grammatical awareness test were calculated. $72 \%$ or 93 student teachers were in the range scores 31-50. This showed that all participants in the study did not perform well in the test. Most of them were at a moderate level. It was generally similar to Shuib's study (2009). He found that whole the respondents in his study did not perform well in the test reflecting a low level of awareness of grammatical knowledge. It indicated that the respondents were at moderate level. Besides, Schoonmaker (2015) revealed that pre-service teachers lacked higher level metalinguistics awareness. It could be seen by their limited ability to explain grammar issues and use proper metalanguage when they answered the test. In this study, although the participants had taken all grammar courses, it did not provide them with experience and skills for grammar. Most of them failed to explain grammatical rules for grammatical errors.

\subsection{The Discussion about Student Teachers' Perception towards Grammatical Awareness}

The data gained from semi-structured interviews were analyzed to answer the second research question "what are the student teachers' perceptions towards grammatical awareness". First, student teachers had different perceptions about understanding of English grammar. Some student teachers thought that understanding English grammar was important. It was supported by Azar (2007), understanding of English grammar helps many students formulate how to say what they mean and helped them lead to successful communication. In addition, Jafari (2016) claimed that student who had grammatical skills and were able to use their grammatical awareness more efficiently, paid much more consideration to the strategies for improvement of reading performance. Moreover, other participants felt that understanding English grammar was difficult. It is in line with Effendi, Rokhyati, Rachman, Rahmawati, and Pertiwi (2017) who found that the 56\% of EFL students had difficulty in understanding the English structures because English structures were very different from the structure of the Indonesian language. From the variety of opinion, we concluded that most of the student teachers were aware of the importance of understanding English grammar but they had difficulties in understanding English grammar. In addition, the result from the next question about student teachers to rate their understanding of English grammar showed that majority of the student teachers admitted sufficient, but some of them felt insufficient in understanding English grammar.

Moreover, from the third question about student teachers' perceptions toward the aspects of English grammar, which were the easiest aspect and the most difficult aspect, the finding showed that most student teachers admitted that metalanguage production task was the easiest aspect whereas the rules and explanations task were the most difficult aspects. Lan (2011) stated that performance of the participants was the worst in explanation tasks. This can be largely due to the cognitive demand of the task (Andrew, 1999). Additionally, most students teachers pointed out that grammar patterns or structures related to the tenses were their most difficulties.

\section{Conclusions and Recommendations}

Based on the findings and discussion of the study, it could be concluded that:

Student teachers of English Education Study Program of one State Islamic University in Indonesia contributed four types of grammatical awareness, namely (1) Metalanguage recognition, (2) Metalanguage production, (3) Identification and grammatical error correction, and (4) Grammatical rules explanation.

In metalanguage recognition, the student teachers' mean score was 21. 35. It was followed by metalanguage production where the student teachers' mean score was 6.02. Then, in identification and grammatical errors correction, the student teachers' mean score was 8.26. The last, in grammatical rules explanation, the student teachers' mean score was 5.66. Thus, Metalanguage recognition was proved to be the easiest part for the student teachers followed by identification and grammatical error correction and metalanguage production. While grammatical rules explanations were proved to be the most difficult part for the student teachers. Then, this study also revealed that student teachers' grammatical awareness was at moderate level. It indicated that the majority of the participants $(72 \%)$ were in the range score $31-50$. 
Second, this study was conducted to find out student teachers' perception towards grammatical awareness. After collecting semi structured interview, from the first question we found that student teachers were aware of the importance of understanding of English grammar although another perception also showed that the student teachers faced the difficulties in understanding of English grammar. Then, student teachers thought that they had sufficiently proficient in English grammar. The second question discussed about aspects of English grammar which posed difficulties to student teachers, which the easiest and the difficulties. We found that the student teachers stated that metalanguage production part was the easiest aspect while the grammatical rules explanation part was the most difficult aspect. The third question was about the possible causes of student teachers of English grammar difficulties. The result showed that student teachers did not understand about the meaning and the use of the grammar rules such as tenses.

The findings in the present study suggest that more efforts need to be made at English student teachers to promote grammatical awareness among aspiring teachers. This is important as it was found that student teacher had poor ability to explain grammatical error.

\section{REFERENCES}

[1] Abrar, M., Mukminin, A., Habibi, A., Asyrafi, F., Makmur, M., \& Marzulina, L. (2018). "If our English isn't a language, what is it?" Indonesian EFL student teachers' challenges speaking English. The Qualitative Report, 23(1), 129-145. Retrieved from http://nsuworks.nova.edu/tqr/vol23/iss1/9

[2] Andrews, S. (1999). 'All these like little name things': A comparative study of language teachers' explicit knowledge of grammar and grammatical terminology. Language Awareness, 8(3), 143-159. Retrieved from http://hdl.handl e.net/10722/42079

[3] Andrews, S. (1994). The grammatical awareness and knowledge of Hong Kong teachers of English. Language and learning. Institute of language in education, Hong Kong. Retrieved from https://eric.ed.gov/?id=ED386066

[4] Azar, B. (2007). Grammar-based teaching: A practitioner's perspective. Teaching English as a Second or Foreign Language (TESL-EJ), 11(2), 1-12. Retrieved from http://www.tesl-ej.org/ej42/a1.pdf

[5] Batias, M., Sepulveda, E. E. R., Munoz, A. C. S., \& Lorena, M. (2011). Integration of the four skills of the English language and its influence on the performance of second grade high school students (Unpublished Doctoral Dissertation). Universidad Del Bio-Bio, Chillan, Chile. Retrieved from http://repobib.ubiobio.cl/jspui/bitstream/12 $3456789 / 306 / 1 / \mathrm{Mu} \% \mathrm{C} 3 \% \mathrm{~B} 1 \mathrm{oz}$ B Bast $\% \mathrm{C} 3 \% \mathrm{ADas}$ Elizab eth.pdf

[6] Cajkler, W., \& Hislam, J. (2002). Trainee teachers' grammatical knowledge: The tension public expectation and individual competence. Language Awareness, 11(3), 161-177.

[7] Celce-Murcia, M., \& Larsen-Freeman, D. (1999). The grammar book: Form, meaning, and use for English language teachers (2nd ed.). New York, NY: Heinle ELT.

[8] Creswell, J.W. (2005). Educational research: Planning, conducting, and evaluating quantitative and qualitative research (2nd ed.). Upper Saddle River, NJ: Pearson Education, Inc.

[9] Creswell, J.W. (2012). Educational research: Planning, conducting, and evaluating quantitative and qualitative research (4th ed.). Boylston Street, Boston: Pearson Education Boston

[10] Effendi, M.S., Rokhyati, U., Rachman, U.A.M., Rakhmawati, A.D., \& Pertiwi. D. (2017). A study on grammar teaching at an English education department in an EFL context. International Journal on Studies in English Language and Literature (IJSELL), 5(1), 42-46. Retrieved from https://www.arcjournals.org/pdfs/ijsell/v5-i1/5.pdf

[11] Greenbaum, S. \& Nelson, G (2002). An introduction to English grammar (2nd). English, London: Pearson Education Limited.

[12] Habibi, A., Mukminin, A., Najwan, J., Sofwan, M., Haswindy, S., Marzulina, L., Sirozi, M., \& Harto, K. (2018). Investigating EFL classroom management in pesantren: A case study. The Qualitative Report, 23(9), 2105-2122.

[13] Han, K., \& Kim, H. (2017). An investigation into the gap between Korean university students' grammatical awareness and perception. Indonesian Journal of Applied Linguistics, 7(1), 117-126. Retrieved from http://ejournal.u pi.edu/index.php/IJAL/article/view/6864

[14] Harmer, J. (2007). The practice of English language teaching. Harlow: Pearson Education.

[15] Husarida, H., \& Dollete, R. (2019). Perceived Effectiveness on the Use of English Language in Teaching Mathematics and Science. Indonesian Research Journal in Education |IRJE|, 3(1), 177-198. https://doi.org/10.22437/irje.v3i1.69 61

[16] Jafari, A. M. (2016). The influence of phonological and grammatical awareness on EFL students' reading performance. Journal of Language Teaching and Research, 7(6), 1164-1173. Retrieved fromhttps://pdfs.semanticschol ar.org/b844/775adb72bc1c5b1a24cf5c0c9d5627460a36.pd $\mathrm{f}$

[17] Lan, T. W. (2011). English metalanguage awareness among primary school teachers in Hong Kong. GEMA Online Journal of Language Studies, 11(1), 1-16. Retrieved from https://hub.hku.hk/bitstream/10722/136353/1/Content.pdf? accept

[18] Makmur., Mukminin, A., Ismiyati, Y., \& Verawati. (2016). In search of good student teachers in writing skill: the impact of different task variance of EFL writing proficiency. International journal of academic research in education, 2(1).

[19] Marzulina, L., Nova, L. P., Herizal., Holandyah, M., Erlina, D., \& Lestari, I. T. (2018). Looking at the link between parents' educational backgrounds and students' English 
achievement. Indonesian Research Journal in Education |IRJE|, 3(1), 57-76. https://doi.org/10.22437/irje.v3i1.6507

[20] Mukminin, A., Ali, R. M., \& Ashari, M. J. (2015). Voices from within: Student teachers' experiences in English academic writing socialization at one Indonesian teacher training program. The Qualitative Report, 20(9), 1394-1407. Retrieved from http://nsuworks.nova.edu/tqr/vol20/iss $9 / 2$

[21] Mukminin, A., Haryanto, E., Sutarno., Sari, S, R., Marzulina, L., Hadiyanto., \& Habibi, A. (2018) Bilingual education policy and Indonesian students' learning strategies. Ilkögretim Online, 17(3), 1204-1223.

[22] Mukminin, A., Masbirorotni, M., Noprival, N., Sutarno, S., Arif, N., \& Maimunah, M. (2015). EFL speaking anxiety among senior high school students and policy recommendations. Journal of Education and Learning, 9(3), 217-225.

[23] Pandarangga, S. (2015). The transformation of English as global language in the world. LiNGUA, 10(2), 90-96. Retrieved from https://www.researchgate.net/publication/2 91206256

[24] Purpura, J. E. (2004). Assessing grammar. New York, NY: Cambridge University Press.

[25] Refnita, L. (2014). Students' grammatical problems in writing simple paragraphs: Lack of grammatical competency or language carelessness (a paper presented in SELT; June 20-21, 2014). Padang, Indonesia. Retrieved from file://C:/Users/pc/Downloads/6716-13368-1-SM.pdf

[26] Savage, K. L., Bitterlin, G., \& Price, D. (2010). Grammar matters: Teaching grammar in adult ESL programs. New York, NY: Cambridge University Press.

[27] Schoonmaker, A. C. (2015). Increasing meta-linguistic awareness as a necessary precursor for pre-service teachers (Doctor's Thesis). University of Central Florida, Orlando, Florida. Retrieved fromhttps://stars.library.ucf.edu/etd/147 $0 /$

[28] Shuib, M. (2009). Grammatical awareness primary school English language teachers. GEMA Online Journal of Language Studies, 9(1), 1675-8021. Retrieved from http://ejournal.ukm.my/gema/article/view/162

[29] Tunde, K. (2007). Adaptation of language awareness test: A focus of cognitive-linguistic and cultural factors in predicting reading development (Master Dissertation). Oslo University. Norway. Retrieved fromhttps://www.duo.uio.n o/bitstream/handle/10852/31920/Master_tunde.pdf?sequen $\mathrm{ce}=1$ 